\title{
ALIENAÇÃO FIDUCIÁRIA DE BENS MÓVEIS, IMÓVEIS E RECUPERAÇÃO JUDICIAL - A (DES) NECESSIDADE DE REGISTRO PRÉVIO
}

\author{
Thiago Santana Rabelo ${ }^{1}$ \\ Carolina Ananias Junqueira Ferraz ${ }^{2}$
}

Resumo: A presente investigação tem o intuito de analisar a necessidade ou não do registro de contrato de alienação fiduciária em garantia de bens móveis e imóveis a luz do Código Civil e da lei de Recuperação Judicial e Falências. Para tanto, a investigação se inicia com o escrutínio do que seria o instituto da alienação fiduciária e sua evolução histórica e legislativa para, na sequência, analisar as hipóteses de exceção dos créditos ao regime de recuperação judicial e sua interpretação a luz dos Tribunais Estaduais e do Superior Tribunal de Justiça.

Palavras-chave: Alienação fiduciária em garantia, Código Civil, Recuperação Judicial, exceção legal, interpretação jurisprudencial do Superior Tribunal de Justiça.

\section{FIDUCIARY ASSEMBLY OF MOVABLE PROPERTY, REAL ESTATE AND JUDICIAL RECOVERY - THE (DES) NEED FOR PRIOR REGISTRATION}

\begin{abstract}
The present investigation has the purpose of analyzing the necessity or not of the registration of fiduciary alienation contract in guarantee of movable and immovable property under the Civil Code and the Law of Judicial Recovery and Bankruptcies. In order to do so, a survey began with the scrutiny of what would be the fiduciary alienation institute and its historical and legislative evolution, in order to analyze, as a hypothesis of exception of the credits to the regime of judicial recovery and its interpretation in light of the State Courts and of the Superior Court of Justice.
\end{abstract}

Keywords: Fiduciary alienation in guarantee, Civil Code, Judicial Recovery, legal exception, jurisprudential interpretation.

\footnotetext{
1 Mestrando em Direito pela Faculdade de Direito Milton Campos. Especialista em Direito Público pela Faculdade Newton Paiva. Graduado em Direito pela Faculdade de Direito Milton Campos. Sócio do escritório Ananias Junqueira Ferraz thiago.santana@ajfadvogados.com.br.

${ }^{2}$ Mestre em Direito Civil pela Pontifícia Universidade Católica de Minas Gerais. Graduada em Direito pela Pontifícia Universidade Católica. Professora do Centro Universitário UMA. Sócia do escritório Ananias Junqueira Ferraz carolinajunqueira@ajfadvogados.com.br.
} 


\section{Introdução}

Não resta dúvida que a lei 11.101/2005 ao disciplinar sobre o procedimento de recuperação judicial e falência trouxe enormes avanços no trato com as empresas em situação de dificuldade econômica ou insolvência financeira.

Se antes o encerramento era regra, agora o polo se inverte restando definitivamente demonstrado que nem toda crise é passível de aniquilamento da pessoa jurídica. Neste sentido, faz-se imperioso relembrar que a continuidade da atividade empresária possui um relevante valor social, uma vez que proporciona a manutenção de empregos, circulação de riquezas com o pagamento de credores e recolhimento de tributos.

Ocorre que a premissa de manutenção da atividade empresária, a qualquer custo, resulta, em inúmeras ocasiões, em um posicionamento jurisprudencial radicalizado capaz de deturpar, a interpretação quanto aos créditos que se submeteriam ou não ao regime recuperacional, submetendo os credores extraordinários a um tratamento ordinário e, consequentemente, distorcendo por completo a natureza dos créditos que possuem.

A bandeira de “justiça” levantada em prol das empresas em dificuldade, como forma de equilibrar os credores e promover o pagamento de todos de maneira igualitária promoveu, diversamente da pretensão inaugural, uma enorme insegurança jurídica.

Neste sentido, faz-se imperioso relembrar que a supramencionada alteração no entendimento jurisprudencial, acabou atribuindo tratamento isonômico a negócios jurídicos celebrados de maneira distintas, com fulcro em hipóteses anteriormente excepcionadas pela lei $11.101 / 2005$.

Cabe ressaltar que, para concessão de crédito, as instituições financeiras, em regra, realizam uma análise criteriosa com o fito de quantificar o custo do mútuo em virtude do risco de não adimplemento da operação. Dentre as inúmeras análises a existência de garantias do contrato, em especial as decorrentes de alienação fiduciária, são as que mais facilitam o acesso ao crédito.

Quando um entendimento jurisprudencial superveniente desconsidera um tratamento extraordinário previsto em lei e, consequentemente, as condições previamente estabelecidas em contratos. Assim, o custo do crédito aumenta dificultando sua concessão e, obstando a capacidade produtiva do mercado. 
O presente trabalho visa analisar a alienação fiduciária através de sua formação histórica, a luz do Código Civil e legislações especiais, as razões fundamentais que levaram o legislador incluir esta garantia entre as exceções previstas na lei 11.101/05 e, o posicionamento dos tribunais, com o fito de estabelecer uma crítica ao recente entendimento jurisprudencial sobre a matéria.

\section{A fidúcia e o seu desenvolvimento histórico -}

A fidúcia teve o seu nascedouro no direito romano como um acordo consensual, de natureza secreta e fundado principalmente na honestidade e confiança estabelecida entre as partes, de forma que o credor alienava determinado bem ao fiduciário lhe obrigando a devolver ou promover destinação específica na forma entabulada entre as partes.

Cabe ressaltar, pela própria natureza do instituto, que o elemento angular e fundamental deste negócio jurídico é a confiança estabelecida entre as partes e, consubstanciada em um valor moral que permeia as relações sociais.

Neste sentido, naturalmente o credor sempre espera do devedor, a restituição do bem após a extinção da dívida já que, por se tratar de ato desprovido de proteção, não há meios de compelir o inadimplente ao cumprimento da obrigação.

A fidúcia, no direito romano, segundo Caio Mario da Silva Pereira (2017, p 337) ocorria através das figuras do fiducia cum amico e fiducia cum creditore.

A primeira modalidade não possuía como finalidade a garantia e ocorria sempre que uma determinada pessoa, em uma situação extraordinária, transferia a um amigo os seus bens com a possibilidade de lhe serem restituídos quando cessada a excepcionalidade.

Diversamente, na segunda modalidade o devedor transferia os seus bens ao credor com a possibilidade de recuperá-los após o cumprimento das obrigações que havia assumido. Assim este modelo apresentava dois momentos diversos, o primeiro decorrente da alienação dos bens realizada pelo devedor e o segundo do retorno desses a sua propriedade.

Faz-se imperioso relembrar, neste sentido, que nas duas modalidades havia transferência de determinado bem ou direito à outra pessoa e, ainda que não houvesse respaldo jurídico à época, esta última, frisa-se, pelo cumprimento de uma obrigação natural, restituía ao antigo proprietário os bens e direitos. 
Pelo exposto, resta evidente que a fidúcia nasce, no direito romano, como uma obrigação natural e, posteriormente, é incorporada nos ordenamentos jurídicos modernos como elemento garantidor do negócio jurídico.

\section{Do desenvolvimento legislativo da alienação fiduciária no ordenamento brasileiro e as suas especificidades}

O instituto da fidúcia foi incorporado ao nosso ordenamento, e sua implementação decorreu da necessidade da criação de um novo direito real de garantia, aperfeiçoando assim as relações jurídicas contratuais antes adstritas a figuras como o penhor e a hipoteca.

Assim, o referido instituto passa a integrar o ordenamento jurídico brasileiro através do Dec. 911/69 que, ao alterar o artigo 66 da lei 4.728/65, acresceu entre as garantias oponíveis aos contratos a alienação fiduciária.

A alienação fiduciária avançou e diversas alterações conformaram o instituto redesenhando-o como atualmente é conhecido como, por exemplo, as alterações inseridas pela lei 9.514/973, que ao impor a transferência imediata do bem ao credor fiduciário em caso de inadimplemento cria uma espécie de propriedade resolúvel.

Em 2004, através da lei $10.931^{4}$ houve alteração da Seção XIV da lei 4.278/65 criando o artigo 66-B, que dispôs sobre a Alienação Fiduciária em Garantia no âmbito do mercado financeiro de capitais e, possibilitou a cessão fiduciária de direitos sobre coisas móveis bem como de título de crédito.

Washington dos Santos (2001, p.33) define alienação fiduciária como uma “cessão de bens em confiança, como garantia de uma dívida: o devedor transfere ao credor um bem de sua propriedade, como garantia da dívida assumida. Após cumprido o compromisso que gerou a dívida o bem será imediatamente restituído”.

\footnotetext{
${ }^{3}$ Importante destacar para a lei 9514/97 a determinação do artigo 23: Art. 23. Constitui-se a propriedade fiduciária de coisa imóvel mediante registro, no competente Registro de Imóveis, do contrato que lhe serve de título. Parágrafo único. Com a constituição da propriedade fiduciária, dá-se o desdobramento da posse, tornando-se o fiduciante possuidor direto e o fiduciário possuidor indireto da coisa imóvel.

${ }^{4} \mathrm{O}$ artigo 42 da lei 10.931/2004 estabelece: “A validade e eficácia da Cédula de Crédito Bancário não dependem de registro, mas as garantias reais, por ela constituídas, ficam sujeitas, para valer contra terceiros, aos registros ou averbações previstas na legislação aplicável, com as alterações introduzidas por esta Lei. ” Em relação as alterações apresentadas pelo artigo 66-B não existe qualquer menção quanto a obrigatoriedade do registro.
} 
Orlando Gomes (1983, p. 325) conceitua como um negócio jurídico pelo qual as partes através da confiança adquirem determinado bem obrigando-se a devolvê-lo quando se verifique o acontecimento o qual tenha se subordinado, como por exemplo, o pagamento.

Caio Mário da Silva Pereira (2017, p379) ao definir propriedade fiduciária ${ }^{5}$ entende como sendo a transferência ao credor do domínio e posse indireta de um bem, sem a tradição efetiva, e como garantia ao pagamento de uma obrigação resolvendo o direito do adquirente com a solução da dívida garantida.

Pode-se, por fim, acrescentar que na alienação fiduciária o credor (fiduciário) obriga o devedor (fiduciante) a transferência da propriedade de bem móvel ou imóvel, fungível ou não, como forma de garantir o cumprimento da obrigação e, durante a vigência do contrato o credor permanece na posse indireta do bem.

Finalizada a obrigação pelo pagamento readquire o alienante a propriedade do bem de forma que o instituto, tal qual aplicado no brasil, cria uma condição resolutiva.

Portanto, da análise das legislações informadas chega-se à conclusão o que o instituto da alienação fiduciária em suas diversas modalidades trata-se de um direito real de garantia, ou seja, vincula o bem ao credor que se torna, a partir de então, titular na qualidade de proprietário fiduciário dos respectivos bens.

\section{Da recuperação judicial}

Após quase 70 anos de vigência do Decreto Lei 7661/45 que cuidava do processamento da falência e concordata, ocorreu a promulgação da lei 11.101/2005 que representou uma adequação necessária ao ambiente econômico nacional.

A Lei de Recuperação Judicial, diferentemente do regramento anterior que focava na impontualidade e insolvência para liquidação imediata da sociedade empresária, agora abarca o princípio da conservação da empresa, com adoção de mecanismos que viabilizam a sua manutenção resguardando esta, durante o período recuperacional, de atos que obstem a continuidade da atividade empresária.

\footnotetext{
${ }^{5}$ Apesar de parte da doutrina considerar alienação fiduciária e propriedade fiduciária como elementos distintos permitimos aqui apresenta-los como sinônimos ante ao objetivo que se busca através deste artigo que seria a interpretação deste perante o Poder Judiciário.
} 
A promulgação da Lei de Recuperação Judicial e Falências promoveu um enorme avanço para a sociedade empresária, na medida em que viabilizou a possibilidade de sua manutenção em situações de crise econômica ressalvando a sua liquidação somente em situação excepcional.

E para tanto o legislador dividiu o procedimento em duas etapas sendo a primeira no momento do deferimento da recuperação judicial, o qual será objeto de maior detalhamento, e o segundo quando da homologação do plano recuperacional.

Com o deferimento do processamento da recuperação judicial a consequência imediata, pela própria natureza do procedimento, é a suspensão de todas as ações em face da recuperanda consoante disposição do artigo $6^{\circ}$ da lei 11.101/2005;

Lei 11.101/05 - Art. $6^{\circ}$ A decretação da falência ou o deferimento do processamento da recuperação judicial suspende o curso da prescrição e de todas as ações e execuções em face do devedor, inclusive aquelas dos credores particulares do sócio solidário.

A análise do artigo traduz a ideia de que a suspensão de todas as ações se daria em caráter incondicional, o que não traduz uma verdade absoluta posto que o próprio ordenamento, estabeleceu quais créditos não se submeteriam ao regime recuperacional, conforme inclusive dispõe o artigo 49, $\S 3^{\circ}$ da lei 11.101/2005;

Lei. 11.101/05 - Art. 49 Estão sujeitos à recuperação judicial todos os créditos existentes na data do pedido, ainda que não vencidos.

(...)

§ 3o Tratando-se de credor titular da posição de proprietário fiduciário de bens móveis ou imóveis, de arrendador mercantil, de proprietário ou promitente vendedor de imóvel cujos respectivos contratos contenham cláusula de irrevogabilidade ou irretratabilidade, inclusive em incorporações imobiliárias, ou de proprietário em contrato de venda com reserva de domínio, seu crédito não se submeterá aos efeitos da recuperação judicial e prevalecerão os direitos de propriedade sobre a coisa e as condições contratuais, observada a legislação respectiva, não se permitindo, contudo, durante o prazo de suspensão a que se refere o $\S 4$ o do art. 6o desta Lei, a venda ou a retirada do estabelecimento do devedor dos bens de capital essenciais a sua atividade empresarial.

Sobre o referido artigo e, em especial no que diz respeito aos contratos de alienação fiduciária esclarece Marlon Tomazette (2017, p.119) que assim, não são abrangidos pela recuperação os créditos do titular da posição de proprietário fiduciário de bens móveis ou imóveis. 
Logo, independentemente do processamento da recuperação judicial, demonstrado inadimplemento do fiduciante quanto ao pagamento do débito, surge para o credor fiduciário a possibilidade de exercer o seu direito sobre o bem dado em garantia.

Perceba-se que o texto legislativo foi cristalino ao estabelecer como legítimo o direito do credor fiduciário de não se submeter ao regime recuperacional, exercendo a persecução legal para transferência da posse do bem e, consequentemente, promovendo a amortização ou liquidação do débito gerado em decorrência impontualidade.

A disposição legislativa por si só não gera dúvidas pois, o objetivo primordial da chancela concedida a essa espécie de credores seria o restabelecimento de sua posse direta da garantia fornecida e, a amortização ou adimplemento da obrigação assumida.

Ainda que, no caso concreto, o bem objeto da alienação fiduciária fosse considerado indispensável a atividade empresária, o que eventualmente impossibilitaria sua retirada imediata do estabelecimento empresarial, não estaria desnaturada a condição do proprietário fiduciário pois o contrato, em regra, foi celebrado dentro da previsão legal e consoante regramento imposto pela legislação.

Ocorre que o tema não é visto de maneira desarmada pelo Tribunais e, em inúmeras situações houve uma deturpação do instituto da alienação fiduciária o qual promoveu um alargamento das suas condicionantes desconstruindo o rol das exceções previstas no artigo 49, $\S 3^{\circ}$ da lei 11.101/2005.

\section{Da interpretação jurisprudencial acerca dos contratos de alienação fiduciária e das distorções provocadas pela ampliação do conceito}

Como apresentado anteriormente, o instituto da alienação fiduciária teve o seu nascedouro através do Dec. Lei 911/69, mas foi através da lei 10.931 que o seu tratamento foi alongado para contemplar contratos em que o instituto é utilizado no âmbito do mercado financeiro de capitais.

Para as legislações referenciadas, resta patente que o objetivo legislativo implícito no ordenamento jurídico brasileiro é possibilitar a transferência imediata da propriedade do tomador de empréstimo ao credor fiduciário e, com isso, possibilitar a concessão de crédito com taxas mais atrativas. 
Ocorre que, como citado anteriormente, as diversas leis que tratam a matéria criaram modalidades distintas de alienação fiduciária e, desta forma, uma terrível colcha de retalhos.

Entretanto, segundo Marlon Tomazette (2017, p. 120) o instituto da alienação fiduciária restaria, no Brasil, divido em três espécies distintas, quais sejam, a primeira constante do Código Civil (artigos 1361 a 1368) considerada por ele como comum e cujo o objeto seria bem móvel infungível; a segunda que abarcaria bens móveis e que estariam abarcadas pela lei n. 4728/65 e Dec./Lei 911/69, aplicável as operações realizadas no mercado financeiro e de capitais e, finalmente, a terceira criada pela lei 9514/97 que alcançam as alienações fiduciárias de bens imóveis.

As duas últimas modalidades descritas acima, são comumente usadas pelas instituições financeiras que, diante do inerente risco da operação e objetivando recuperação certa do crédito, promovem a concessão monetária em operações garantidas com o patrimônio do tomador de crédito.

Consequentemente, a alienação fiduciária, nestes casos, promove uma diminuição do risco e a redução no custo médio do crédito fornecido e, consequentemente, viabilizando uma maior concessão de crédito capaz de fomentar a atividade empresarial.

Após 12 anos da vigência da lei 11.101/2005, entretanto, uma interpretação equivocada sobra a aplicação do instituto da alienação fiduciária como exceção ao regime recuperacional tem criado óbice ao implemento do referido proposito.

Neste diapasão, cabe trazer à baila, inicialmente, o tratamento da matéria realizado no artigo 1.361 do Código Civil

\footnotetext{
Art. 1.361. Considera-se fiduciária a propriedade resolúvel de coisa móvel infungível que o devedor, com escopo de garantia, transfere ao credor. $\S 1$ o Constitui-se a propriedade fiduciária com o registro do contrato, celebrado por instrumento público ou particular, que lhe serve de título, no Registro de Títulos e Documentos do domicílio do devedor, ou, em se tratando de veículos, na repartição competente para o licenciamento, fazendo-se a anotação no certificado de registro.

§ 20 Com a constituição da propriedade fiduciária, dá-se o desdobramento da posse, tornando-se o devedor possuidor direto da coisa.

$\S 3$ 3 A propriedade superveniente, adquirida pelo devedor, torna eficaz, desde o arquivamento, a transferência da propriedade fiduciária.
}

Da análise do aludido artigo, em especial do seu primeiro parágrafo, infere-se que a propriedade fiduciária de coisa móvel infungível será constituída através do registro do 
contrato no cartório de Registro de Títulos e Documentos do domicilio do devedor e, na

hipótese de veículos, no órgão competente para licenciamento.

Contudo, tribunais estaduais, na aplicação da Lei 11.101/2005, aumentaram a

abrangência desse artigo de sorte que a obrigação de registro do contrato no cartório de notas do domicílio do devedor deveria ocorrer sobre todas as hipóteses de alienação fiduciária fossem os bens infungíveis ou não, incluindo veículos.

Neste sentido, o Tribunal de Justiça do Estado de São Paulo editou a súmula 60 “ $a$ propriedade fiduciária constitui-se com o registro do instrumento no registro de títulos e documentos do domicílio do devedor" 6

Importante acrescentar que o posicionamento firmado pelo Tribunal de Justiça do Estado de São Paulo, considerado um dos mais relevantes tribunais do país, contaminou o entendimento de outros tribunais como a exemplo se cita o posicionamento firmado pelo Tribunal de Justiça do Estado do Rio Grande do Sul através do seguinte julgado:

AGRAVO DE INSTRUMENTO. RECUPERAÇÃO JUDICIAL. CESSÃO DE CRÉDITO. AUSÊNCIA DE REGISTRO DO CONTRATO. SUJEIÇÃO DOS CRÉDITOS À RECUPERAÇÃO JUDICIAL. PRELIMINAR AFASTADA. Da norma processual aplicável ao feito 1.No caso em exame a decisão recorrida foi publicada em período compreendido até 17/03/2016. Assim, segundo os enunciados do Superior Tribunal de Justiça sobre a aplicação do novel Código de Processo Civil, há a incidência da legislação anterior, de acordo com o posicionamento jurídico uniforme daquela Corte, que tem a competência para regular a forma de aplicação da lei federal. 2.A interpretação precitada coaduna com os princípios conformadores da atual legislação processual civil, que dizem respeito a não ocasionar prejuízo à parte ou gerar surpresa a esta com a modificação do procedimento em relação aos atos já efetivados, consoante estabelece o art. $9^{\circ}$, caput, e art. 10, ambos do novel Código Processo Civil. Mérito do recurso em exame 6. O princípio da preservação da empresa, insculpido no art. 47 da Lei 11.101/2005, dispõe que a recuperação judicial tem por objetivo viabilizar a superação da situação de crise econômico-financeira do devedor, a fim de permitir a manutenção da fonte produtora, do emprego dos trabalhadores e dos interesses dos credores, promovendo, assim, a preservação daquela, sua função social e o estímulo à atividade econômica. 7.Verifica-se pela análise dos autos que os créditos da parte agravante têm origem dos contratos de cessão de direitos creditórios n. ${ }^{\circ}$ 1263306/15, 1268129/15, 1275186/15 e 85008161/15, avençados entre as partes. Possibilidade de contemplação pela hipótese prevista no art. 49, § $3^{\circ}$, da Lei $n^{\circ}$ 11.101/2005 somente dos contratos registrados no Registro de Títulos e Documentos, conforme preceitua o art. 1.361, §1º do Código Civil e $o$ art. 42 da Lei n. ${ }^{\circ}$ 10.931/04. 8.No presente feito os contratos que deram origem aos créditos da parte embargada não foram registrados previamente no Ofício Registral competente da Comarca de domicílio da parte devedora. 9. Dessa forma, os créditos arrolados pela parte embargada sujeitam-se

6 TRIBUNAL DE JUSTIÇA DO ESTADO DE SÃO PAULO. Súmulas. Disponível em: <http://www.tjsp.jus.br/download/secaodireitoprivado/sumulas.pdf>. Acesso em: 20 fev. 2018. 
aos efeitos da recuperação judicial, não sendo possível que aquela proceda às amortizações pretendidas, uma vez que no caso em exame inaplicável a exceção prevista no art. 49, § $3^{\circ}$, da Lei $n^{\circ} 11.101 / 2005$. Negado provimento ao agravo de instrumento. (TJRS, 2016, on-line)

Dessa forma, ao impor o registro dos títulos, os referidos Tribunais alteraram a abrangência do Código Civil aplicando-o em situações tratadas por regramento específico e, como consequência, desnaturaram o instituto da alienação fiduciária.

Assim, os créditos que antes eram excepcionados na lei de recuperação judicial passam a vigorar entre os credores submetidos ao regime recuperacional.

Todavia, é de suma importância uma análise apurada do referido artigo como forma de demonstrar o equívoco da interpretação que está sendo imposta em nossos tribunais, notadamente em relação a obrigatoriedade do registro do contrato de alienação fiduciária e, eventual reclassificação do mesmo como crédito submetido ao processo recuperacional.

Inicialmente, faz-se imperioso relembrar que a alienação fiduciária constituída em cédula de crédito bancário é matéria expressamente tratada pela Lei 10.931/04, in verbis:

\footnotetext{
Art. 42. A validade e eficácia da Cédula de Crédito Bancário não dependem de registro, mas as garantias reais, por ela constituídas, ficam sujeitas, para valer contra terceiros, aos registros ou averbações previstas na legislação aplicável, com as alterações introduzidas por esta Lei.
}

Neste contexto, resta afastada a aplicabilidade do Código Civil nos contratos em que a alienação fiduciária, como forma de garantia, é constituída em cédula de crédito bancária.

Neste diapasão, cabe ainda relembrar que a supramencionada lei, expressamente, impõe a obrigatoriedade do registro para que a garantia se torna oponível à terceiros e não, como faz a jurisprudência do Egrégio Tribunal de Justiça de São Paulo, como pressuposto de eficácia do contrato.

A partir da análise histórica do instituto objeto do presente artigo, pode-se concluir que a alienação fiduciária em suas diversas modalidades é direito real de garantia, ou seja, vincula o bem ao credor que se torna a partir de então titular, na qualidade de proprietário fiduciário, dos respectivos direitos.

Pode-se, pois, concluir que, se a cédula de credito bancária não for registrada, o proprietário fiduciário não poderá, perante terceiros de boa-fé, exercer seu direito de 
consolidação da propriedade do bem, mas, igualmente não podemos concluir que este direito não valerá perante o devedor.

E, por consequência, incabível seria considerar constituída uma obrigação principal, como exemplo um mútuo bancário materializado por uma cédula de crédito e, ao mesmo tempo, considera-la sem efeito em decorrência da inexistência de registro da garantia, que se frisa, é uma obrigação assessória.

Por fim, cabe asseverar que sendo válida e eficaz perante o devedor que faz o pleito recuperacional, a cédula garantida por alienação fiduciária deve ser excluída dos efeitos da recuperação judicial deferida.

\section{Do retorno a razoabilidade promovido pelo STJ}

Nesse sentido, apesar dos inúmeros exageros cometidos pelos tribunais estaduais, em especial do Egrégio Tribunal de Justiça do Estado de São Paulo acerca do tema aqui debatido, coube ao Superior Tribunal de Justiça encerrar a celeuma criada.

Através do Recurso Especial Resp. 1559457/MT, o Tribunal Superior firmou o posicionamento de que a constituição de garantia oriunda de cessão fiduciária de direitos sobre coisas móveis e títulos de crédito, ocorreria pela própria contratação e, por consequência, independentemente de registro, conforme destacado abaixo

RECURSO ESPECIAL. RECUPERAÇÃO JUDICIAL. CESSÃO FIDUCIÁRIA SOBRE DIREITOS SOBRE COISA MÓVEL E SOBRE TÍTULOS DE CRÉDITO. CREDOR TITULAR DE POSIÇÃO DE PROPRIETÁRIO FIDUCIÁRIO SOBRE DIREITOS CREDITÍCIOS. NÃO SUJEIÇÃO AOS EFEITOS DA RECUPERAÇÃO JUDICIAL, NOS TERMOS DO $\S 3^{\circ}$ DO ART. 49 DA LEI N. 11.101/2005. MATÉRIA PACÍFICA NO ÂMBITO DAS TURMAS DE DIREITO PRIVADO DO STJ. PRETENSÃO DE SUBMETER AOS EFEITOS DA RECUPERAÇÃO JUDICIAL, COMO CRÉDITO QUIROGRAFÁRIO, OS CONTRATOS DE CESSÃO FIDUCIÁRIA QUE, À ÉPOCA DO PEDIDO DE RECUPERAÇÃO JUDICIAL, NÃO SE ENCONTRAVAM REGISTRADOS NO CARTÓRIO DE TÍTULOS E DOCUMENTOS DO DOMICÍLIO DO DEVEDOR, COM ESTEIO NO $\S 1^{\circ}$ DO ART. 1.361-A DO CÓDIGO CIVIL. INSUBSISTÊNCIA. RECURSO ESPECIAL IMPROVIDO. (STJ, 2016, online) 
Ao longo da decisão, o ilustre Ministro Relator Marco Aurélio Bellizze justificou desnecessidade do registro de contrato de alienação fiduciária por inúmeros fundamentos dentre os quais destacaremos os mais relevantes.

Como argumentação inicial reafirmou o posicionamento de que a alienação fiduciária de coisa fungível, bem como a cessão fiduciária de direitos sobre coisas móveis e títulos de crédito possuem natureza jurídica de propriedade fiduciária e, portanto, apresentam-se como exceção legal ao regime de recuperação judicial consoante disposição prevista no artigo 49, §3 da lei 11.101/2005.

Avançando sobre o tema esclareceu que previsão constante do Código Civil versa exclusivamente sobre propriedade fiduciária bens móveis infungíveis acrescentando ainda, que as demais espécies de propriedade fiduciária submeteriam a regramento previstos em leis especiais, de forma que a aplicação do Código Civil se daria em caráter subsidiário, consoante previsão constante do artigo 1368-A.

Art. 1.368-A. As demais espécies de propriedade fiduciária ou de titularidade fiduciária submetem-se à disciplina específica das respectivas leis especiais, somente se aplicando as disposições deste Código naquilo que não for incompatível com a legislação especial.

E dessa forma a exigência de registro para efeito de constituição da propriedade fiduciária não se encontra presente na lei 4728/95, especificamente em seu artigo 66-B, que dispõe sobre a cessão fiduciária de direito sobre coisas móveis e títulos de crédito que pela própria natureza apresentam-se como bens fungíveis, ou seja, de característica diversa ao que abarca do Código Civil.

Para os ministros do Superior Tribunal de Justiça, a propriedade fiduciária é constituída a partir da própria contratação de forma que, reiterando o que já foi aqui informado, o registro do contrato apresenta-se tão somente para produção de efeitos em relação a terceiros em razão da publicidade do ato.

Como complemento restou ainda posicionado que a lei 10.931/04, em seu artigo 42, determina que a cédula de crédito bancário não depende de registro de forma que as garantias que a acompanham, apenas para valer contra terceiros, ficariam sujeitas a registro.

E para finalizar notadamente no que diz respeito a inclusão ou não no regime de recuperação judicial e, considerando os contratos elencados da na lei 11.101, o ilustre Ministro esclareceu; 
Como assinalado, a propriedade fiduciária encontra-se devidamente constituída a partir de sua contratação, afigurando-se absolutamente válida e eficaz entre as partes. Essa garantia, "para valer contra terceiros", ou seja, para ser oponível contra terceiros, deve ser registrada. De se notar que o credor titular da posição de proprietário fiduciário sobre direitos creditícios (excluído dos efeitos da recuperação judicial, segundo o $\S 3^{\circ}$ do art. 49 da Lei n. 11.101/2005) não opõe essa garantia real aos credores da recuperanda, tal como impropriamente assentou o magistrado de piso, mas sim aos devedores da recuperanda (contra quem, efetivamente, se farão valer o direito ao crédito, objeto da garantia), o que robustece a compreensão de que a garantia sob comento não diz respeito à recuperação judicial.

Assentado que está que o direito creditício sobre o qual recai a propriedade fiduciária é de titularidade (resolúvel) do banco fiduciário, este bem, a partir da cessão, não compõe o patrimônio da devedora fiduciante (que sequer detém sobre ele qualquer ingerência) -, sendo, pois, inacessível aos seus demais credores e, por conseguinte, sem qualquer repercussão na esfera jurídica destes. Não se antevê, por conseguinte, qualquer frustração dos demais credores da recuperanda que, sobre o bem dado em garantia (fora dos efeitos da recuperação judicial), não guardam legítima expectativa.

Aliás, justamente sob o aspecto da devedora, naturalmente ciente da sua situação de dificuldade financeira, ao eleger o momento de requerer sua recuperação judicial, escolha, também, ao seu alvedrio, quais dívidas contraídas seriam ou não submetidas à recuperação judicial.

Nessa perspectiva, em manifesta contrariedade aos ditames da lei de regência, vislumbra-se a hipótese em que a empresa em dificuldades financeiras, com o deliberado propósito de obter crédito, a despeito de não possuir lastro para tanto, contrate empréstimo bancário, garantido por cessão fiduciária de direitos creditícios, e, no mesmo dia ou logo em seguida à mencionada contratação, ingresse com seu pedido de recuperação judicial.

Nessa hipotética situação, o referido credor, embora fiduciário e, por lei, não sujeito aos efeitos da recuperação judicial, teria que submeter seu crédito ao concurso de credores por uma manobra da empresa em crise, que, ao seu talante, procedeu ao pedido de recuperação judicial imediatamente à contratação, sem que a instituição financeira pudesse providenciar o registro, que, como evidenciado, tem finalidade exclusivamente publicista.

De todo modo, uma vez constituída a cessão fiduciária, o que se dá a partir da contratação - e não do registro -, o correlato credor não se submete aos efeitos da recuperação judicial, e, por conseguinte, sobre o bem dado em garantia (direitos creditícios), os demais credores da recuperanda não possuem legítima expectativa de direitos. (STJ, 2016, on-line)

Perceba-se, portanto, que as leis não possuem palavras inúteis de forma que o próprio corpo legislativo apresenta as soluções e esclarecimentos necessários quanto o registro do contrato.

Dessa forma, e como não poderia ser de outra maneira, a previsão constante do Código Civil abarcaria apenas os contratos de alienação fiduciária de bens móveis infungíveis figura atípica, em regra, a maioria dos contratos de mutuo realizados com instituições financeiras. 
Aliado a isso conforme reportado pelo próprio Relator e pela doutrina os efeitos constantes do não registro refletiriam tão somente sobre terceiros permanecendo, portanto, os seus efeitos em relação aos contratantes.

Assim, em um regime de recuperação judicial onde a empresa busca, de maneira sucinta, a apresentação aos credores de todos os ativos e passivos com um plano de pagamento que deverá ser submetido a deliberação, parece pouco lógico que bens que não lhe pertençam, pela espécie contratual que lhes enforma, sejam desnaturados por condições que em momento algum violaram os termos da lei.

Em complemento, é de suma importância ratificar que inúmeros contratos celebrados diariamente fundam-se primeiramente na boa-fé, princípio norteador de qualquer relação jurídica e que não permite atalhos ou deturpações.

\section{Considerações finais}

Conforme apresentado o instituto da fidúcia existe há muito no direito, em especial no direito romano através das figuras do fiducia cum amico e fiducia cum creditore que surgiram através da confiança existente entre as partes no qual o devedor transferia um bem de sua propriedade ao credor, obrigando-se este a devolvê-lo quando cumprida uma obrigação futura, como por exemplo, o pagamento.

A evolução legislativa da alienação fiduciária em nosso ordenamento pátrio, o qual adveio inicialmente com a através do Dec. 911/69 que alterou o artigo 66 da lei 4728/65, e posteriormente, com a inclusão do instituto da alienação fiduciária de bem imóvel na lei 10931, com a criação da alienação fiduciária em garantia no âmbito do mercado financeiro de capitais que possibilitou a cessão fiduciária de direitos sobre coisas móveis bem como de título de crédito.

Avançando foi apresentada as características básicas acerca do processamento da recuperação judicial onde restou apresentada a sua divisão em duas etapas sendo a primeira quando do deferimento do processamento que determina a suspensão de todas as ações em curso e, a segunda, quando da homologação do plano de recuperação judicial.

Atendo-se exclusivamente a primeira fase da recuperação judicial foi explicado que o artigo 49, §3º da lei 11.101/2005 excetua algumas espécies creditórias, em especial, os contratos de alienação fiduciária de sorte que, caso não sejam bens indispensáveis a atividade 
empresaria, surge para o credor fiduciário o direito de promover a busca do bem e não se submeter ao regime recuperacional.

Todavia, apesar do cristalino direito constante da lei de recuperação judicial houve, por parte dos Tribunais, uma interpretação equivocada ao considerar que o requisito fundamental para a validade do contrato de alienação fiduciária seria o seu registro nos termos do artigo 1361, $\S 1^{\circ}$ do Código Civil.

E nesses termos houve através do egrégio Tribunal de Justiça do Estado de São Paulo a edição da súmula 60, que somente considerou válido os contratos que eventualmente estivessem registrados perante o Cartório de Registro de Títulos e documentos do domicilio do devedor.

A adoção do posicionamento apresentado pelo referido Tribunal contaminou outros tribunais estaduais e, como consequência, promoveu a desnaturação de inúmeros contratos que antes excepcionados ao regime legal agora estariam obrigados a figurar dentro do processo de recuperação judicial na qualidade de credores quirografários, o que promoveu uma enorme insegurança jurídica afetando diretamente credores que se valiam da modalidade contratual excetuada para a concessão de crédito a taxas menores.

A matéria extremamente controversa foi submetida ao Superior Tribunal de Justiça que de maneira sucinta e, conforme restou demonstrado ao longo do artigo, considerou que a obrigatoriedade de registro serviria apenas para oponibilidade a terceiros de sorte que a ausência deste em nata desnaturaria o contrato celebrado.

Portanto, dúvida não resta que a racionalidade apresentada pelo Superior Tribunal de Justiça equilibrou a relação entre o credor e o devedor fiduciário promovendo segurança jurídica quanto ao contrato celebrado e, acima de tudo, reafirmando o princípio da boa-fé posto que não seria lícito a empresa recuperanda alegar vícios na formação do contrato celebrado quando ciente acerca da modalidade contratada. 


\section{REFERÊNCIAS}

BARROS NETO, Geraldo Fonseca. Aspectos Processuais da Recuperação Judicial. Florianópolis: Conceito Editorial, 2014.

CAMPOS FILHO, Moacyr Lobato. Falência e Recuperação. Belo Horizonte: Del Rey, 2006.

CARVALHO, Maria Serina Areias. Propriedade Fiduciária. Tese (Mestrado em Direito) Faculdade de Direito, Universidade de São Paulo. São Paulo, 2009.

CONJUR. STJ acerta rumos da alienação fiduciária em recuperação judicial. Disponível em: $<$ https://www.conjur.com.br/2016-jul-08/renaldo-limiro-stj-acerta-rumos-alienacaofiduciaria-recuperacao>. Acesso em: 06 fev. 2018.

CONJUR. É desnecessário registrar alienação fiduciária na recuperação judicial. Disponível em: <é desnecessário registrar alienação fiduciária na recuperação judicial>. Acesso em: 10 fev. 2018.

COSTA, Daniel Carnio. Comentários completos à lei de recuperação de empresas e falências. Curitiba: Juruá, 2015.

DIDIER JR., Fredie. Curso de direito processual civil: introdução ao direito processual civil, parte geral e processo de conhecimento. v. 1. 17. ed. Salvador: Jus Podivm, 2015.

FRANÇA, Erasmo Valladão Azevedo e Novaes. Arts. 35 a 46. In: SOUZA JÚNIOR, Francisco Satiro de.; PITOMBO, A. de Moraes. (Org.). Comentários à Lei de Recuperação de Empresas e Falência. São Paulo: Ed. Revista dos Tribunais, 2005.

GONÇALVES, Aroldo Plínio. Técnica Processual e Teoria do Processo. 1. ed. Rio de Janeiro: Aide, 1992.

GOMES, Orlando. Direitos reais. 8. ed. Rio de Janeiro: Forense, 1983.

GONTIJO, Vinícius. J. M. A Natureza de Jurisdição Voluntária da Recuperação Judicial de Empresas. Revista da Faculdade de Direito Milton Campos, v. 28, p. 01-11, 2014.

GONTIJO, Vinícius. J. M. Falência e recuperação de empresas: acordo de credores na assembleia geral. Revista de Direito Privado (São Paulo), v. 49, p. 340, 2012.

PENTEADO, Mauro Rodrigues. Capítulo I: Disposições Preliminares. In: SOUZA JÚNIOR, Francisco Satiro de; PITOMBO, Sérgio A. de Moraes (Coords.). Comentários à Lei da recuperação de empresas e falência: Lei 11.101/2005 - Artigo por artigo. 2. ed. rev., atual. e ampl. São Paulo: Editora Revista dos Tribunais, 2007.

PEREIRA, Caio Mário da Silva, Instituições de direito civil - IV/ Atual. Carlos Edison do Rêgo Monteiro Filho. - 29. ed. rev. e atual. - Rio de Janeiro: Forense, 2017. 
SANTOS, Washington dos. Dicionário jurídico brasileiro. Belo Horizonte: Del Rey, 2001.

STJ. RECURSO ESPECIAL: Resp 1.559.457 MT 2015/0136561-0. Relator: Ministro Marco Aurélio Bellizze. DJ 17/12/2015. Disponível em: < http://www.stj.jus.br/SCON/jurisprudencia/doc.jsp?livre=1559457\&b=ACOR\&p=true\&l=10 $\underline{\& i=5}>$. Acesso em: 23 março 2018

TJRS. AGRAVO DE INSTRUMENTO: Ag. 70067500579. Relator: Desembargador Jorge Luiz Lopes do Canto. DJ 25/05/2016. Disponível em: $<$ http://www.tjrs.jus.br/busca/search?q=70067500579+\&proxystylesheet=tjrs_index\&client=t jrs_index\&filter $=0 \&$ getfields $=* \& a b a=$ juris\&entsp $=$ a_politica-

site \&wc $=200 \& w c \_m c=1 \& o e=U T F-8 \& i e=U T F-$

8\&ud=1\&sort=date\%3AD\%3AS\%3Ad1\&as_qj=\&site=ementario\&as_epq=\&as_oq=\&as_eq $=\& a s \_q=+\#$ main_res_juris $>$.

TJSP. Súmulas. Disponível em: <http://www.tjsp.jus.br/download/secaodireitoprivado/sumulas.pdf>. Acesso em: 20 fev. 2018.

TOMAZETTE, Marlon. Curso de direito empresarial: Falência e Recuperação de Empresas. 5 ed. São Paulo-SP: Atlas, 2017 